\title{
An optimized method for the generation of AFLP markers in a stingless bee (Melipona quadrifasciata) reveals a high degree of intracolonial genetic polymorphism*
}

\author{
Gustavo R. MAKERT ${ }^{\mathrm{a}}$, Robert J. PAXTON ${ }^{\mathrm{b}}$, Klaus HARTFELDER ${ }^{\mathrm{c}}$ \\ ${ }^{a}$ Depto. Genética, Faculdade de Medicina de Ribeirão Preto, Universidade de São Paulo, Ribeirão Preto, Brazil \\ ${ }^{\mathrm{b}}$ School of Biological Sciences, Queen's University Belfast, Belfast, UK \\ ${ }^{\mathrm{c}}$ Depto. Biologia Celular e Molecular e Bioagents Patogênicos, Faculdade de Medicina de Ribeirão Preto, \\ Universidade de São Paulo, Ribeirão Preto, Brazil
}

Received 22 June 2005 - Revised 26 February 2006 - Accepted 28 February 2006

\begin{abstract}
This study describes an optimized protocol for the generation of Amplified Fragment Length Polymorphism (AFLP) markers in a stingless bee. Essential modifications to standard protocols are a restriction enzyme digestion ( $E c o \mathrm{RI}$ and $T r u 1 \mathrm{I})$ in a two-step procedure, combined with a touchdown program in the selective PCR amplification step and product labelling by incorporation of $\alpha\left[{ }^{33} \mathrm{P}\right] \mathrm{dATP}$. In an analysis of 75 workers collected from three colonies of Melipona quadrifasciata we obtained 719 markers. Analysis of genetic variability revealed that on average $32 \%$ of the markers were polymorphic within a colony. Compared to the overall percentage of polymorphism (44\% of the markers detected in our bee samples), the observed rates of within-colony polymorphism are remarkably high, considering that the workers of each colony were all offspring of a singly mated queen.
\end{abstract}

amplified fragment length polymorphism / genotyping / stingless bee / genetic polymorphism / Melipona / Apidae

\section{INTRODUCTION}

Since its introduction over ten years ago (Vos et al., 1995), the methodology for generating amplified fragment length polymorphism (AFLP) markers has become increasingly popular for genotyping and genome mapping. A brief PubMed survey in 2005 returned over 1400 entries, most representing AFLP studies on plants and microorganisms, yet only 48 entries on the use AFLP strategies in insects. This is surprising considering the advantages of AFLP analysis over traditional DNA fingerprinting protocols such as RFLP (higher resolution) and RAPD (higher reproducibility) (Mueller and Wolfenbarger, 1999;

Corresponding author: G.R. Makert, gustavo@rge.fmrp.usp.br

* Manuscript editor: Walter S. Sheppard
Garcia et al., 2004; Nybom, 2004; Bensch and Åkesson, 2005). Even though insects are generally rather small, it is not the quantity of DNA required for individual analyses that should hamper the generation of AFLP markers. Rather, when initiating a study on the stingless bee, Melipona quadrifasciata, we noted a series of problems with standard protocols that required optimization before reliable and consistent results could be obtained on genetic variation within and between colonies.

Stingless bees of the genus Melipona have long attracted research interest because of their peculiar mode of caste determination. Distinct from all other highly eusocial bees, the brood combs of Melipona species lack specific queen cells; rather, all male and female brood is reared in cells of similar size, provided with similar amounts of larval food (Ihering, 1903). The proportion of queens in the female brood 
is exceptionally high in most Melipona species and shows relatively little variation when compared to the frequency of male brood (Velthuis et al., 2005). These findings have spurred the formulation of two hypotheses. The first is a proximate explanation for caste determination, which proposes a genetic mechanism of caste determination. It is based on a two locus-two allele system where only females that are heterozygous at both loci can become queens. It was postulated over fifty years ago (Kerr, 1946, 1950), but despite a series of attempts it has never been conclusively confirmed experimentally or genetically. The second is an ultimate explanation for caste ratios in this genus which proposes that caste determination may be modelled on the basis of a potential conflict of interest over caste fate (Ratnieks, 2001). This model, developed using a singlelocus inclusive fitness approach, attributes a certain degree of choice over caste fate (self determination) to the developing larvae.

Testing these hypotheses requires screening large numbers of polymorphic loci. Yet, genetic variability within species or even within colonies of stingless bees is still poorly studied, and different approaches have resulted in quite discrepant estimates. While levels of polymorphisms were observed to be low in isozyme studies (Falcão and Contel, 1990; Machado and Contel, 1991), polymorphism levels of 25-45\% were detected for RAPD markers when comparing Melipona quadrifasciata colonies (Tavares et al., 2001; Waldschmidt et al., 2002). Since RAPD markers are frequently criticized for their notoriously low levels of reproducibility, we decided to adopt an AFLP approach to test whether this methodology can generate markers of appropriate quantity and reproducibility. Since AFLP combines the advantages of RAPD with the reliability of RFLP, this seemed like a promising strategy because RFLP mapping of the mitochondrial genome of different stingless bees already indicated high levels of genetic diversity among species (Francisco et al., 2001; Weinlich et al., 2004).

We initiated this study with a commercially available and frequently employed system (AFLP Analysis system I, Invitrogen) which has been successfully used in a num- ber of insect species, such as the gall midge Orseolia oryzae (Behura et al., 2000; Katiyar et al., 2000), the fruit fly Ceratitis capitata (Corsini et al., 1999), the damselfly Nehalennia irene (Wong et al., 2001), the sweet potato whitefly, Bemisia tabaci (Göçmen and Devran, 2002), the dung beetle Onthophagus taurus (Simmons et al., 2004) and also the honey bee, Apis mellifera (Suazo and Hall, 1999; Rueppell et al., 2004). Since we could not obtain reproducible results (consistent bands using the same DNA extracts as templates) with this system in the stingless bee M. quadrifasciata, even after testing different strategies of DNA extraction to obtain DNA of adequate purity for an insect AFLP study (Reineke et al., 1998), we decided to go through a complete optimization process of the AFLP reactions with this species. The detailed description of critical steps given here may be of use to overcome similar problems in other problematic species and promote the use of this powerful methodology in a wider range of bee species.

\section{MATERIALS AND METHODS}

\subsection{Bee samples}

We collected a total of 580 adults of the stingless bee Melipona quadrifasciata Lepeletier from three colonies kept in the apiary of the Department of Genetics on the campus of the University of São Paulo at Ribeirão Preto over a period of one year. Brood combs containing brood in the late pupal stages were removed from the colonies and were kept in Petri dishes in a temperature controlled environment $\left(28^{\circ} \mathrm{C}\right)$. Bees emerging from the combs were sorted according to sex and caste and were snap-frozen individually in liquid nitrogen. Subsequently they were stored in $99 \%$ ethanol at $-20{ }^{\circ} \mathrm{C}$.

\subsection{DNA extraction}

DNA was extracted from the thoraces of individuals using a high-salt extraction protocol (Paxton et al., 1996). Per bee we used $350 \mu \mathrm{L}$ SET buffer (0.15 M NaCl, 0.02 M Tris, 1.0 mM EDTA pH 8.0), supplemented with $6.5 \mu \mathrm{L}$ proteinase $\mathrm{K}(20 \mathrm{mg} / \mathrm{mL})$ and $15.5 \mu \mathrm{L}$ SDS (25\%) for digestion at $55{ }^{\circ} \mathrm{C}$ for $2 \mathrm{~h}$. Subsequently, $300 \mu \mathrm{L}$ of $6 \mathrm{M} \mathrm{NaCl}$ were 
added and the samples were vortexed and centrifuged at $15000 \mathrm{~g}$ for $10 \mathrm{~min}$. The supernatant containing DNA (550 $\mu \mathrm{L})$ was transferred to a new tube with $150 \mu \mathrm{L} 10 \mathrm{mM}$ Tris- $\mathrm{HCl}(\mathrm{pH} 8.0)$ to which $1.4 \mathrm{~mL}$ ice-cold absolute ethanol was added. This was stored overnight at $-20{ }^{\circ} \mathrm{C}$ to precipitate the DNA, then centrifuged at $12000 \mathrm{~g}$ for $15 \mathrm{~min}$ to pellet the DNA. The pellet was rinsed in $70 \%$ ethanol, vacuum dried and dissolved in $100 \mu \mathrm{L}$ distilled water. This extraction yielded approximately $5 \mu \mathrm{g}$ DNA per bee, and $1 \mu \mathrm{L}$ of this DNA (approximately $50 \mathrm{ng}$ ) was sufficient for each AFLP reaction.

\subsection{Two-step restriction enzyme digestion, adapter primer ligation and amplification}

Instead of the frequently used single-step digestion with restriction enzymes, we performed a twostep digestion. In the first reaction, the EcoRI digestion, $1 \mu \mathrm{L}$ DNA was added to $20 \mu \mathrm{L} \mathrm{Y+/Tango}$ buffer (Fermentas) with $0.5 \mathrm{U}$ EcoRI enzyme (Fermentas). This mixture was incubated for $30 \mathrm{~min}$ at $37{ }^{\circ} \mathrm{C}$. For the second digestion step, $0.5 \mathrm{U}$ Tru $1 \mathrm{I}$ enzyme (Fermentas) in $1 \mu \mathrm{L} \mathrm{Y}+/$ Tango buffer was added to the reaction mixture of the first digestion step and rapidly heated to $65{ }^{\circ} \mathrm{C}$ for $30 \mathrm{~min}$. At this temperature, EcoRI is inactivated and Tru $1 \mathrm{I}$ has its optimal activity. For ligation of adaptor primers (all primers from Sigma-Genosys) to the restriction enzyme cleavage sites, we added to digestion products $(21 \mu \mathrm{L})$ a mixture $(4 \mu \mathrm{L})$ of 2.5 pmol EcoRI adapter and 25 pmol TrulI-adapter (Tab. I) with $0.5 \mathrm{U}$ T4 DNA-ligase (Fermentas) in T4 ligation buffer. These core primers are complementary to the EcoRI and Tru1I (MseI) adaptor oligonucleotides and have one additional 3' nucleotide (A or $\mathrm{C}$ respectively). The ligation reaction mix was incubated at $22^{\circ} \mathrm{C}$ for $3 \mathrm{~h}$. After ligation, the reaction mixture was diluted with 5 volumes of $\mathrm{dd}_{2} \mathrm{O}$ and stored at $-20{ }^{\circ} \mathrm{C}$.

The amplification protocol followed the original two-step amplification strategy (Vos et al., 1995). For the preamplification reaction, $60 \mu \mathrm{M}$ dNTPs, $25 \mathrm{ng}$ of each preamplification primer (Tab. I), $200 \mu \mathrm{M}$ spermidine and $0.5 \mathrm{U}$ Taq DNA polymerase in 10× reaction buffer (Finnzymes) were brought to a volume of $11.5 \mu \mathrm{L}$ before adding $1 \mu \mathrm{L}$ of the ligation reaction as template. The preamplification reaction commenced with a 10 min denaturation step $\left(95^{\circ} \mathrm{C}\right.$ ), followed by a 30 cycle program (denatura- tion $30 \mathrm{~s}$ at $95^{\circ} \mathrm{C}$, annealing $60 \mathrm{~s}$ at $56^{\circ} \mathrm{C}$ and extension $60 \mathrm{~s}$ at $72{ }^{\circ} \mathrm{C}$ ) and terminating with a $20 \mathrm{~min}$ extension step at $72{ }^{\circ} \mathrm{C}$. For the second (selective) amplification, the products of the preamplification reaction were diluted with 20 volumes of $\mathrm{dd}_{2} \mathrm{O}$.

The second (selective) amplification reactions were carried out in a total volume of $10 \mu \mathrm{L}$ by adding $1 \mu \mathrm{L}$ of the diluted preamplifiction reaction to a mix $(9 \mu \mathrm{L})$ of $1 \mu \mathrm{L} 10 \times$ amplification buffer (same as preamplification), $6 \mu \mathrm{M}$ dATP and $200 \mu \mathrm{M}$ each of dCTP, dGTP and dTTP, $25 \mathrm{ng}$ of one of the EcoRI and $25 \mathrm{ng}$ of one of the Tru1I amplification primers (Tab. I), $200 \mu \mathrm{M}$ spermidine, $0.5 \mathrm{U}$ Taq DNA polymerase and $1.25 \mu \mathrm{Ci} \alpha\left[{ }^{33} \mathrm{P}\right] \mathrm{dATP}$. The amplification reaction protocol started with a 10 min denaturation step $\left(95^{\circ} \mathrm{C}\right)$, followed by a touchdown cycle profile ( 45 cycles total), and terminated with a $20 \mathrm{~min}$ extension step at $72{ }^{\circ} \mathrm{C}$. The touchdown profile (denaturation $30 \mathrm{~s}$ at $95^{\circ} \mathrm{C}$, annealing $60 \mathrm{~s}$ and extension $60 \mathrm{~s}$ at $72{ }^{\circ} \mathrm{C}$ ) started with an annealing temperature of $65^{\circ} \mathrm{C}$ which was gradually reduced by $0.7^{\circ} \mathrm{C}$ in each of the following 12 cycles. In the final 33 cycles, the annealing temperature was kept constant at $56^{\circ} \mathrm{C}$. All amplification reactions were performed in an $\mathrm{MJ}$ Research PTC-100 thermal cycler.

\subsection{Electrophoresis, autoradiography and analysis of AFLP bands}

The amplification products of each reaction $(10 \mu \mathrm{L})$ were mixed with $7 \mu \mathrm{L}$ stop solution $(20 \mathrm{mM}$ EDTA; $0.1 \%$ xylene cyanol; $0.1 \%$ bromophenol blue; $96 \%$ formamide) and denatured for $5 \mathrm{~min}$ at $96{ }^{\circ} \mathrm{C}$ before they were electrophoretically separated under denaturing conditions (ca. $50{ }^{\circ} \mathrm{C}$ ) on a $43 \mathrm{~cm}$ long sequencing gel ( $8 \mathrm{M}$ urea; $6 \%$ polyacrylamide). As marker for comparison between gels and as internal standard to monitor the amplification reactions, we used a single DNA sample amplified by the primer combination EcoRI-aac/TrulI-cta. The gels were dried for $2 \mathrm{~h}$ at $80^{\circ} \mathrm{C}$ before exposure to X-ray film (Kodak Biomax) for 3 days.

In the 25 samples per colony of Melipona worker DNA that were run in parallel on each film, we counted all clearly visible bands and scored them as total bands per primer combination. In a second round we scored the percentage of polymorphic markers for each primer set and colony. By pairwise comparisons between the samples from the three colonies we next ascertained in a cumulative manner the total number of bands and the number of 
Table I. Oligonucleotide adapters and primers.

\begin{tabular}{ll}
\hline Oligonucleotide & Sequence \\
\hline EcoRI adapter forward & 5'-CTCGTAGACTGCGTACC-3' \\
EcoRI adapter reverse & 5'-AATTGGTACGCAGTCTAC-3' \\
Tru1I adapter forward & 5'-GACGATGAGTCCTGAG-3' \\
Tru1I adapter reverse & 5'-TACTCAGGACTCAT-3' \\
preamplification EcoRI-a & 5'-GACTGCGTACCAATTCA-3' \\
preamplification Tru1I-c & 5'-GATGAGTCCTGAGTAAC-3' \\
amplification $E c o$ RI-aag & 5'-GACTGCGTACCAATTCAAG-3' \\
amplification $E c o R I-a a c$ & 5'-GACTGCGTACCAATTCAAC-3' \\
amplification Tru1I-cta & 5'-GATGAGTCCTGAGTAACTA-3' \\
amplification Tru1I-cat & 5'-GATGAGTCCTGAGTAACAT-3' \\
\hline
\end{tabular}

polymorphic bands that could be obtained by each primer combination.

\subsection{Microsatellite analysis}

For the analysis of microsatellite loci in the three colonies of Melipona quadrifasciata, we used 50 DNA samples of workers that were also used in the AFLP analyses. Of the microsatellite primers developed for Melipona bicolor (Peters et al., 1999), Mbi105 and Mbi233 were the ones that gave the best results with the $M$. quadrifasciata samples, in terms of polymorphism and band resolution. The amplification reactions were carried out in a total volume of $25 \mu \mathrm{L}$, with PCR-Master Mix (Promega) and $400 \mathrm{nmol}$ of Mbi105 or Mbi233 primer and $1 \mu \mathrm{L}$ of template DNA under the following conditions: $94{ }^{\circ} \mathrm{C}$ for $3 \mathrm{~min}, 40$ cycles of $94{ }^{\circ} \mathrm{C}$ for $30 \mathrm{~s}$, $52{ }^{\circ} \mathrm{C}$ for $30 \mathrm{~s}$ and $72{ }^{\circ} \mathrm{C}$ for $60 \mathrm{~s}$, followed by a final extension at $72{ }^{\circ} \mathrm{C}$ for $10 \mathrm{~min}$. The amplification products were separated by electrophoresis in $6 \%$ polyacrylamide gels and revealed by silver staining (Sanguinetti et al., 1994).

\section{RESULTS}

\subsection{AFLP Protocol optimization}

Since our initial attempts with a commercial AFLP kit did not give satisfactory results with DNA extracted from workers of the stingless bee $M$. quadrifasciata because bands generated by the same DNA template were not reproducible across AFLP trials,we systematically tested different DNA extraction procedures, restriction enzyme digestion protocols, and amplification and product labelling protocols. The final working protocol for this species is detailed in Section 2: Materials and Methods. Typical results of the series of adaptations and optimization steps are presented in Figure 1.

The first step in the optimization process was the choice of the DNA extraction method. We initially tested a modified phenol/chloroform extraction that includes a proteinase $\mathrm{K}$ digestion step and addition of SDS. This method has been tested for genomic DNA analyses of stingless bees (Waldschmidt et al., 1997). Next, we tested an extraction protocol that uses a high salt $(6 \mathrm{M} \mathrm{NaCl}) /$ ethanol precipitation of DNA in combination with SDS and a proteinase $\mathrm{K}$ digestion step. However, when used in conjunction with the commercial AFLP kit, we did not obtain satisfactory results with any these protocols (Fig. 1A), even though all these methods resulted in high quality DNA. With the high-salt extraction method, which we finally adopted because of its ease of use, we obtained approximately $5 \mu \mathrm{g}$ DNA per bee thorax.

Consequently, we decided to redesign the AFLP protocol itself, and this involved a series of sequential modifications. We had noticed that AFLP protocols with insect genomic DNA frequently substituted $M s e I$, the enzyme used in the original protocol in conjunction with EcoRI (Vos et al., 1995), for another restriction enzyme. Since we did not want to substitute the AFLP adaptor and primer combinations, we decided to test the efficiency of the restriction enzyme Tru1I in combination with EcoRI. Tru1I cuts at the same recognition site as MseI, but has a much higher optimum 
A

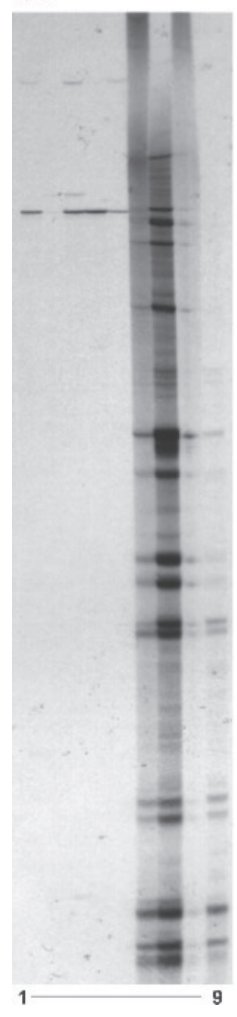

B

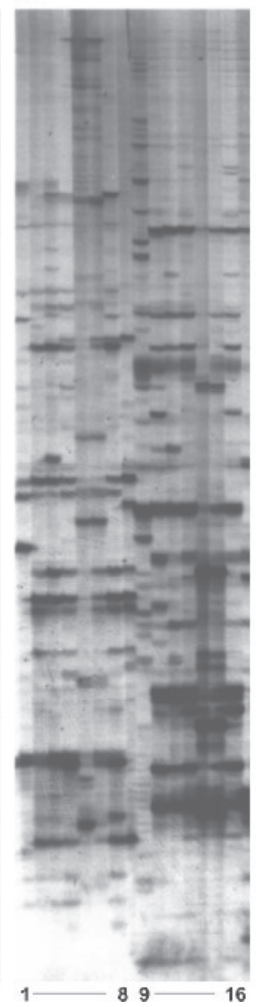

C

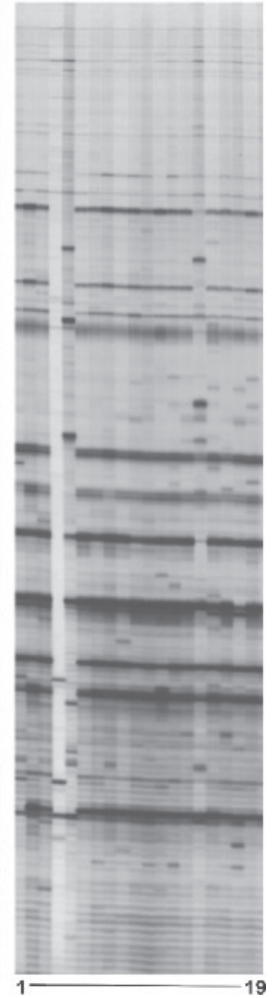

Figure 1. Results of optimization steps in the AFLP protocol for the stingless bee, Melipona quadrifasciata. All DNA extractions on worker bees were performed with a high-salt buffer, SDS and proteinase $\mathrm{K}$ digestion. Fragments of digestion reactions were labelled by incorporation of $\alpha\left[{ }^{33} \mathrm{P}\right] \mathrm{dATP}$ and resolved on sequencing gels under denaturing conditions. (A) single-step digestion with EcoRI and $M s e I$ and two-step amplification with AFLP primers (Invitrogen) performed with different mixes of dNTP and varying concentrations of primers $(0.3-1.0 \mathrm{ng} / \mu \mathrm{L})$, shown in lanes 1-9; (B) two-step digestion with EcoRI and Tru1I followed by a two-step amplification with two sets of AFLP primers (lanes 1-8 EcoRI-aag/Tru1I-cat, lanes 916 EcoRI-aag/Tru1I-cta; these primers had the same sequence as those shown in Figure $1 \mathrm{~A})$; (C) digestion and the first round of amplification was performed as in Figure $1 \mathrm{~B}$, but the second, selective amplification followed a touchdown protocol. The 19 samples were analyzed with primer combination EcoRI-aag/Tru1I-cat. temperature than MseI and EcoRI, thus requiring a two-step digestion protocol. While needing more pipetting steps, our two-step protocol could be performed in two $30 \mathrm{~min}$ incubations, whereas the usual double digest performed in a single-step in most AFLP protocols is much more time consuming, requiring an incubation for 2-3 h (Vos et al., 1995; Behura et al., 2000; Simmons et al., 2004). An initial typical result of the two-step digestion protocol performed on DNA extracted with the high-salt protocol is illustrated in Figure 1B. It shows a clear improvement when compared to Figure 1A, in terms of the number of scoreable bands. Yet, the markers were still too inconsistent, appearing in some reactions but not others using the same DNA template.

The refinement of the banding pattern into a high resolution and consistent AFLP profile for individual $M$. quadrifasciata workers was finally achieved by optimization of the amplification conditions into a touchdown proto- col (Fig. 1C). The preamplification step is a PCR with core primers that are complementary to the adapter sequence, plus one additional nucleotide at the 3' end (Forward Primer EcoRI-a; Reverse Primer Tru1I-c). The second amplification round uses longer selective adapter primers that have three overhanging nucleotides at their 3' end. Starting this second PCR round with a Tm of $65^{\circ} \mathrm{C}$ and gradually dropping the $\mathrm{Tm}$ to $56^{\circ} \mathrm{C}$ in a touchdown protocol allowed for higher stringency in the amplification reactions. As detection method, we opted for radioactive labelling of amplification products by incorporation of $\alpha\left[{ }^{33} \mathrm{P}\right] \mathrm{dATP}$ during elongation. This direct labelling is frequently used in microsatellite analyses (Paxton et al., 1996) and has also been employed in AFLP fingerprinting (Katiyar et al., 2000). It eliminates the primer labelling step required in most radioactive PCR-based genotyping protocols. This direct labelling protocol may subtly affect band intensity in the autoradiographs 
since the degree of $\alpha\left[{ }^{33} \mathrm{P}\right] \mathrm{dATP}$ incorporation will depend on the AT-content of the synthesised fragments, though the effect is likely to be minor.

\subsection{AFLP fingerprinting in Melipona bees}

On the basis of the optimized protocol we could consistently amplify DNA samples of $M$. quadrifasciata workers that had emerged from brood combs of three colonies. Sampling bees as they emerged from the brood combs controlled for genetic origin, as drifting of adult workers among colonies can be a frequent phenomenon in these bees (Palmer et al., 2002). The results for the primer pair EcoRIaag and Tru1I-cat are shown in Figure 2 for a set of 25 workers from each colony, illustrating the large number of scorable markers obtained with this protocol. In addition, it illustrates that most polymorphic markers fall into the median gel region (fragments from 100 to $1000 \mathrm{bp}$ ), which has excellent resolution. The larger markers (fragments $>1000 \mathrm{bp}$ ) are often represented as relatively weak bands, whereas the lower region of the gel (fragments $<100 \mathrm{bp}$ ) contains mainly monomorphic markers. Table II lists the total number of AFLP bands and the percentage that are polymorphic, detected by the four combinations of the two specific amplification primers. From these we calculated the percentage of polymorphic markers within each colony and the percentage overall polymorphism. A notable result is that with only four primer combinations we could score a mean of 630 markers for each M. quadrifasciata colony. Across all primer combinations for all colonies, $44 \%$ of markers were polymorphic. This figure represents the overall polymorphism for this set of colonies, whereas intracolony polymorphism varied between 27 and 38\%. Intracolony polymorphism thus accounts for most of the genetic variation in this dataset. Nevertheless, there is still additional variation that can be detected when comparing rates of genetic polymorphism within colonies (27-38\%) to the observed overall polymorphism $\left(\chi^{2}, 22.85 / 2, P<\right.$ $0.01)$. This genetic variation at the population level is not unexpected and is probably due to the mating of virgin queens with genetically unrelated males.

In contrast, the high degree of genetic variation among females collected from the same M. quadrifasciata colony was a surprising result if we consider that these colonies should have originated from a single queen that had mated with a single male. To confirm monandry and monogyny, we genotyped 50 workers by analysis of two microsatellite loci (Mbi105 and Mbi233). These showed allele patterns that were consistent with monogyny and monandry (data not shown), indicating that workers were full sisters.

\section{DISCUSSION}

\subsection{Optimization steps in the AFLP protocol for Melipona quadrifasciata}

High quality genomic DNA is a general demand in AFLP protocols and has proven critical in AFLP reactions with different insect species (Reineke et al., 1998). Generally, these methods use CTAB and a phenol/chloroform extraction protocol. We modified this because previous studies describing DNA extraction procedures for stingless bees have shown the importance of a step incorporating proteinase $\mathrm{K}$ digestion and the substitution of CTAB by SDS (Waldschmidt et al., 1997) before the phenol/chloroform extraction. In addition, we tested a high-salt DNA extraction procedure that is frequently employed in microsatellite studies on bees (Paxton et al., 1996). Since we did not obtain satisfactory results when using any of these extracts as DNA templates in conjunction with a commercial AFLP kit we concluded that the problems were more likely in the digestion and/or amplification steps, and not because of poor quality of extracted DNA. We decided to opt for the high-salt DNA extraction protocol because it is well-suited for a high-throughput protocol due to its relative simplicity and the low toxicity of chemicals employed.

The combination of restriction enzymes that has been explored and successfully standardized for AFLP analyses in plants and also 


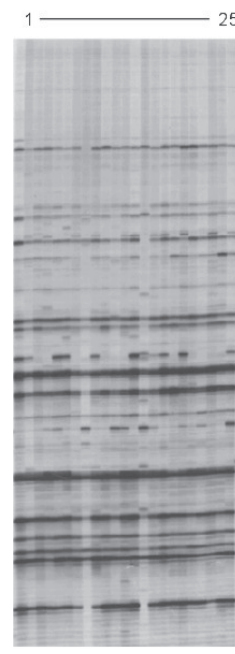

colony 21

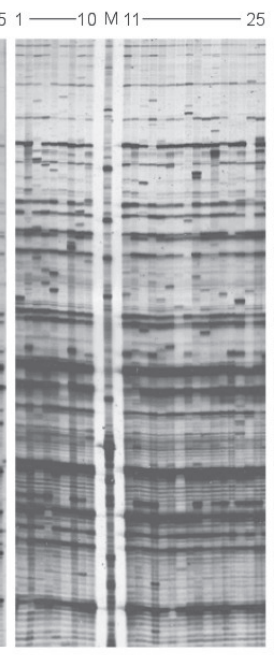

colony 48

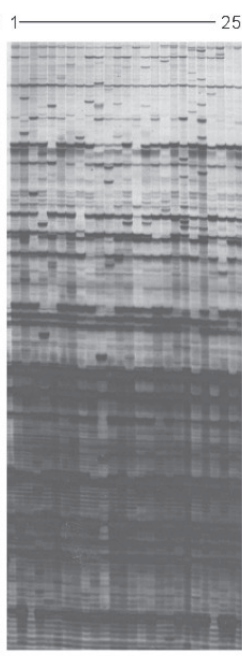

colony 3
Figure 2. AFLP results for workers sampled from three colonies of Melipona quadrifasciata. Amplification reactions shown in this panel were performed with primer combination EcoRI-aag/Tru1I-cat. The marker (M) shown in the panel for colony 48 was always generated as an internal marker by amplification of digested DNA for the same bee with the primer combination EcoRIaac/Tru1I-cta. In the electrophoresis runs it permitted consistent assignment of bands across gels.

Table II. AFLP markers scored for three Melipona quadrifasciata colonies with four sets of primers. For each colony, 25 workers were sampled and analyzed. The total number of polymorphic markers for each colony (last column) represents estimates for intracolony genetic polymorphism, whereas the total of polymorphic markers for all colonies, obtained from a cumulative marker analysis of the three colonies (last line) gives an estimate of overall genetic polymorphism for this species.

\begin{tabular}{lccccc}
\hline & primer set 1 & primer set 2 & primer set 3 & primer set 4 & all primers \\
\hline colony 21 & & & & & \\
$\mathrm{n}$ workers & 25 & 25 & 25 & 25 & 100 \\
total \# bands & 157 & 149 & 156 & 123 & 585 \\
polymorphic & 48 & 36 & 43 & 31 & 158 \\
$\begin{array}{l}\text { \% polymorphic } \\
\text { colony 48 }\end{array}$ & & & & & 27.0 \\
n workers & 25 & 25 & 25 & 25 & 100 \\
total \# bands & 160 & 148 & 175 & 171 & 654 \\
polymorphic & 71 & 56 & 72 & 51 & 250 \\
$\%$ polymorphic & & & & & 38.2 \\
colony 3 & & & & & \\
n workers & 25 & 25 & 25 & 25 & 100 \\
total \# bands & 158 & 151 & 168 & 190 & 667 \\
polymorphic & 54 & 52 & 54 & 47 & 207 \\
$\%$ polymorphic & & & & & 31.0 \\
\hline all colonies & & & & & \\
$\mathrm{n}$ workers & 75 & 75 & 75 & 75 & 300 \\
total \# bands & 168 & 171 & 185 & 195 & 719 \\
polymorphic & 88 & 72 & 87 & 69 & 316 \\
$\%$ polymorphic & & & & & 44.0 \\
\hline
\end{tabular}


most animals is EcoRI with MseI. Insects seem to be an exception in this respect, since even within the relatively few technical reports on insect species we found descriptions of two new enzyme combinations, EcoRI and PstI in the potato beetle (Hawthorne, 2001) and PstI and TaqI in the silkworm (Tan et al., 2001). This suggests that the choice of restriction enzymes is an important step that demands attention in the establishment of AFLP protocols with insect species. In our experiments we substituted Tru1I for MseI in a two-step digestion and amplified the fragments in a touchdown-PCR protocol. With these modifications we obtained reproducible AFLP results with amounts of DNA that were at least 10 times lower than those used in most other studies on insects (Corsini et al., 1999; Behura et al., 2000; Hawthorne, 2001).

An interesting question to be asked in this context, is why AFLP fingerprinting and QTL mapping performed in a single digestion step with EcoRI and MseI worked well for Apis cerana, A. nigrocincta (Smith et al., 2003) and A. mellifera (Arechavaleta-Velasco and Hunt, 2004; Rueppell et al., 2004), but not for the closely related stingless bees that we investigated. The frequent substitution of $\mathrm{Mse}$ I in restriction enzyme combinations for AFLP fingerprinting in insect species (Hawthorne, 2001; Tan et al., 2001) may be related to differing base composition of their genomes, especially AT-richness, and thus the probability of recognition site frequency. For the present case, however, this argument should not apply since $M s e I$ and Tru1I differ in temperature optima but not in restriction site. An interesting alternative to the protocol we present in this study could be a three-enzyme digestion system (Smith et al., 2003).

\subsection{Genetic polymorphism in Melipona quadrifasciata}

The degree of overall genetic polymorphism detected by AFLP analysis in our dataset is similar to that observed in previous studies that employed RAPD approaches on either drones of $M$. quadrifasciata (Tavares et al., 2001), or a much larger number of colonies collected from a wide geographical range (Waldschmidt et al., 2002). Not surprisingly, all these DNA-based dominant marker systems revealed higher degrees of genetic polymorphism than isozyme studies that only examined one or few loci (Falcão and Contel, 1990; Machado and Contel, 1991). Our results based on an AFLP methodology confirm the RAPD results at the population level. In addition, they show that a large part of this genetic variability is in fact due to an unexpectedly high level of polymorphism within colonies.

The high genetic variability that we observed within colonies of $M$. quadrifasciata poses an interesting problem that needs to be discussed at two levels. The first one is related to the mechanism(s) that may generate such genetic variation, and the second one concerns its population genetic implications. In relation to the first aspect, the high degree of polymorphism suggests that each locus may have several allelic states (maximum 3 per colony) with differing dominance relations among them and/or that some loci exhibit codominant rather than dominant inheritance. AFLP bands are generally treated as dominant markers, but careful quantitative analysis has also revealed evidence for codominance (Piepho and Koch, 2000).

An alternative (or additional) mechanism that could account for the observed withincolony genetic variation would be a high recombination frequency. A much elevated recombination frequency was found in the honey bee, Apis mellifera (Hunt and Page, 1995; Beye et al., 1999), exceeding by a factor of five the recombination frequencies in other Hymenoptera, including a bumble bee, Bombus terrestris (Gadau et al., 2001). Such high recombination frequencies are possibly related to levels of social organization. Particularly at the transition from primitively eusocial (bumble bees) to highly eusocial organization (honey bees) an increase in recombination frequencies could produce a genetically more diverse worker force and might reduce susceptibility to pathogen attacks (Gadau et al., 2001).

Maintaining a genetically diverse worker population may be a much more severe problem for stingless bees than for the honey bee with its multiple mating system and a 
swarming process that disperses genotypes over a relatively large area. With the exception of the facultatively polygynous species Melipona bicolor (Nogueira-Neto, 1997; Velthuis et al., 2006), all stingless bees colonies are headed by a single queen and in most cases, these queens had mated with a single male only (Paxton et al., 1999; Peters et al., 1999). Furthermore, the swarming process in stingless bees is not an abrupt fission between the mother and daughter colonies, but rather occurs over a prolonged period. It involves intense traffic of workers and frequent transport of materials between the old nest and the new site (Engels and Imperatiz-Fonseca, 1990; Nogueira-Neto, 1997), and therefore dispersal by swarming is slow and spatially restricted. The obvious consequences for small populations would be a decrease in genetic diversity if there were no counteracting mechanisms to maintain it. The significant contribution of workers to male production in many stingless bee species (Tóth et al., 2002, 2004; Paxton et al., 2003; Velthuis, 2005) in conjunction with a high recombination frequency could represent mechanims that allow maintenance of sufficiently high genetic diversity in even relatively small populations of stingless bees. Even though high recombination rates have so far only been demonstrated for honey bees (Hunt and Page, 1995; Gadau et al., 2001), studies on karyotype (Rocha et al., 2002) and mitochondrial genome evolution (Weinlich et al., 2004; Arias et al., 2006) suggest that stingless bees could harbor rather flexible genomes, as well.

In conclusion, we describe an optimized and efficient protocol for AFLP fingerprinting of a highly eusocial bee. This protocol primarily differs from the original one (Vos et al., 1995) in using a two-step restriction enzyme digestion with EcoRI and Tru1I. The large number of markers obtained in an analysis of worker bees from three colonies of the stingless bee M. quadrifasciata makes plain the potential of this optimized AFLP protocol in advanced genetic studies on stingless bees, especially for high resolution analyses as required for linkage analyses. Such linkage analysis on large numbers of queens, workers and males collected from single colonies should reveal whether or not and how many loci segregate with caste phenotype, thus allowing one to address the long-standing question of a genetic predisposition to caste in the genus Melipona.

In addition, AFLP-based linkage maps may provide a means to investigate the proposed association between levels of eusociality and recombination rates. Stingless bees are an interesting group for exploring this association. They are closely related to honey bees (Michener, 2000; Engel, 2001) and have attained a similar level of social organization. But they differ from honey bees in their sociogenetic colony structure since the workers comprising a stingless bee colony are generally all full sisters, produced by a singly mated queen (Paxton et al., 1999; Peters et al., 1999; Paxton, 2000; Palmer et al., 2002).

\section{ACKNOWLEDGEMENTS}

We would like to thank Wolf Engels and Thomas Haug for hosting parts of this project at the University of Tübingen, Germany, Paulo Nogueira Neto for providing colonies used in this study, and to Weyder Santana for assistance in the collection of bees. Valuable comments on a previous version of the manuscript were made by Deborah Smith. This research was supported by a DAAD/CAPES doctoral fellowship to GRM and a grant from the Deutsche Forschungsgemeinschaft to RJP.

Résumé - Une méthode optimisée pour générer des marqueurs AFLP chez une abeille sans aiguillon (Melipona quadrifasciata) révèle un fort degré de polymorphisme génétique intra colonie. Les études de génétique des populations et de cartographie des liaisons génétiques nécessitent la production d'une grande quantité de marqueurs polymorphiques exploitables avec fiabilité. La méthode de l'AFLP (polymorphisme de longueur du fragment de restriction) peut générer rapidement des centaines de marqueurs reproductibles, permettant ainsi de caractériser le génotype avec une résolution élevée à des coûts relativement bas et une efficacité en temps élevée. Elle a été largement appliquée à la caractérisation des souches bactériennes et des cultivars de plantes et trouve maintenant son application dans le génotypage animal. Les espèces d'insectes représentent souvent un défi pour cette technique, car elles requièrent fréquemment des étapes d'optimisation dans le protocole AFLP. Notre étude présente un tel 
protocole optimisé pour une abeille sans aiguillon, Melipona quadrifasciata Lepeletier. Les modifications les plus importantes apportées aux protocoles standards comportent une digestion de l'enzyme de restriction (EcoRI et Tru1I) dans une procédure en deux temps, combinée avec un programme «touchdown » (diminution progressive de la température d'hybridation des amorces) à l'étape d'amplification sélective par PCR et le marquage du produit par l'incorporation d' $\alpha\left[{ }^{33} \mathrm{P}\right] \mathrm{dATP}$ (Fig. 1).

Lors d'une analyse de 75 ouvrières prélevées dans 3 colonies de $M$. quadrifasciata, nous avons obtenu un total de 719 marqueurs (Fig. 2). L'analyse de la variabilité génétique a révélé un polymorphisme moyen des marqueurs intra-colonie de $32 \%$ (Tab. II). Comparé au pourcentage global des marqueurs polymorphiques $(44 \%)$ détecté dans nos échantillons d'abeilles, les taux observés de polymorphisme intra-colonie sont remarquablement élevés, étant donné que les ouvrières d'une colonie descendent toutes d'une même reine fécondée une fois. Nous considérons que cela peut être dû à un taux élevé de recombinaisons, semblable à celui observé chez l'Abeille domestique (Apis mellifera L.). En raison de sa grande efficacité le protocole optimisé peut fournir un outil intéressant pour générer des cartes de liaisons génétiques pour les abeilles sans aiguillon, par exemple pour des études comparatives d'organisation du génome. En outre l'analyse de la ségrégation des marqueurs AFLP par le phénotype de caste peut fournir un outil pour aborder de manière empirique l'hypothèse de longue date et fort débattue de la prédisposition génétique des castes chez ce genre d'abeilles sans aiguillon.

Melipona / abeille sans aiguillon / génotypage / polymorphisme génétique / AFLP / Apidae

Zusammenfassung - Die Optimierung einer AFLP-Marker-Methode für Stachellose Biene deckt einen hohen genetischen Polymorphismus in Völkern von Melipona quadrifasciata auf. Populationsgenetische Studien und Untersuchungen zur genetischen Kopplung von Loci erfordern die Erstellung einer grossen Anzahl zuverlässig auswertbarer Marker. Die Amplifizierte Fragmentlängen Polymorphismus (AFLP)-Methode ist in der Lage, innerhalb kurzer Zeit hunderte reproduzierbarer Marker zu produzieren und somit eine hochauflösende Genotypierung bei verhältnismässig geringen Kosten und hoher Zeiteffizienz zu leisten. Diese Methode wird inzwischen häufig zur Charakterisierung von Bakterienstämmen und pflanzlichen Kultivaren eingesetzt und findet nun auch häufiger Anwendung in der Genotypierung bei Tieren. Insekten stellen in dieser Hinsicht offensichtlich eine Herausforderung dar, da bei ihnen diese Methode oft umfassende Optimierungen in den Versuchsprotokollen erfordert. Die vorliegende Untersuchung stellt ein optimiertes Protokoll für ei- ne Stachellose Biene, Melipona quadrifasciata, vor. Die wichtigsten Veränderungen gegenüber Standardprotokollen sind der Restriktionsenzymverdau (EcoRI und Tru1I) in zwei Schritten, kombiniert mit einem Touchdown-Programm im selektiven PCRAmplifizierungsschritt und der Produktmarkierung durch den Einbau von $\alpha\left[{ }^{33} \mathrm{P}\right] \mathrm{dATP}$ (Abb. 1).

In einer Untersuchung, die mit 75 Arbeiterinnen aus drei $M$. quadrifasciata Völkern durchgeführt wurde erzielten wir insgesamt 719 Markerbanden (Abb. 2), wobei durchschnittlich $32 \%$ dieser Marker einen genetischen Polymorphismus innerhalb der jeweiligen Kolonie zeigten (Tab. II). Verglichen mit dem Gesamtpolymorphismus von $44 \%$ zwischen den drei Völken war der Anteil polymorpher Marker innerhalb der einzelnen Völker vergleichsweise hoch, insbesondere wenn man betrachtet, dass die Königinnen, die diese Arbeiterinnen produzierten, mit jeweils nur einem Drohn verpaart waren. Eine Erklärung hierfür könnte eine mit der Honigbiene vergleichbare hohe Rekombinationsrate darstellen.

Durch seine hohe Effizienz bietet sich dieses optimierte Protokoll auch für vergleichende Studien zur Genomorganisation an, z.B. zur Erstellung von Kopplungskarten des Genoms Stachelloser Bienen. Ausserdem kann die Analyse der Segregation einzelner Marker mit dem Kastenphänotyp eventuell ein Werkzeug darstellen, die kontrovers diskutierte genetische Basis der Kastendetermination bei dieser Gattung Stachelloser Bienen aufzuklären.

Amplifizierter Fragmentlängen Polymorphismus / Genotypierung / Stachellose Biene / genetischer Polymorphismus / Melipona / Apidae

\section{REFERENCES}

Arechavaleta-Velasco M.E., Hunt G.J. (2004) Binary trait loci that influence honey bee (Hymenoptera: Apidae) guarding behavior, Ann. Entomol. Soc. Am. 97, 177-183.

Arias M.C., Brito R.-M., Francisco F.O., Moretto G., Oliveria F.F., Silvestre D., Sheppard W.S. (2006) Molecular markers as a tool for population and evolutionary studies in stingless bees, Apidologie 37, 259-274.

Behura S.K., Nair S., Sahu S.C., Mohan M. (2000) An AFLP marker that differentiates biotypes of the Asian rice gall midge (Orseolia oryzae, WoodManson) is sex-linked and also linked to avirulence, Mol. Gen. Genet. 263, 328-334.

Bensch S., Åkesson M. (2005) Ten years of AFLP in ecology and evolution: why so few animals? Mol. Ecol. 14, 2899-2914.

Beye M., Hunt G.J., Page R.E., Fondrk M.K., Grohmann L., Moritz R.F.A. (1999) Unusually high recombination rate detected in the sex locus 
region of the honey bee (Apis mellifera), Genetics 153, 1701-1708.

Corsini G., Manubens A., Lladser M., Lobos S., Seelenfreund D. (1999) AFLP analysis of the fruit fly Ceratitis capitata, Focus (GIBCO-BRL) 21, $72-73$.

Engel M.S. (2001) A monograph of the Baltic amber bees and evolution of the Apoidea (Hymenoptera), Bull. Am. Mus. Nat. Hist. 259, 5-192.

Engels W., Imperatriz-Fonseca V.L. (1990) Caste development, reproductive strategies, and control of fertility in honey bees and stingless bees, in: Engels W. (Ed.), Social Insects - an evolutionary approach to castes and reproduction, Springer Verlag, Berlin, pp. 167-230.

Falcão T.M.M.A., Contel E.P.B. (1990) Genetic variability in narural populations of Brazilian social bees. I. Isozyme patterns and polymorphism for esterases and total protein, Rev. Bras. Genet. 13, 731-754.

Francisco F.O., Silvestre D., Arias M.C. (2001) Mitochondrial DNA characterization of five species of Plebeia (Apidae: Meliponini): RFLP and restriction maps, Apidologie 32, 323-332.

Gadau J., Gerloff C.U., Krüger N., Chan H., SchmidHempel P., Wille A., Page R.E. (2001) A linkage analysis of sex determination in Bombus terrestris L. (Hymenoptera: Apidae), Heredity 87, 234-242.

Garcia A.A.F., Benchimol L.L., Barbosa A.M.M., Geraldi I.O., Souza C.L.J., Souza A.P. (2004) Comparison of RAPD, RFLP, AFLP and SSR markers for diversity studies in tropical maize inbred lines, Genet. Mol. Biol. 27, 579-588.

Göçmen H., Devran Z. (2002) Determination of genetic variation in populations of Bemisia tabaci in Antalya, Turk. J. Agric. For. 26, 211-216.

Hawthorne D.J. (2001) AFLP-based genetic linkage map of the Colorado potato beetle Leptinotarsa decemlineata: sex chromosomes and a pyrethroidresistance candidate gene, Genetics 158, 695-700.

Hunt G.J., Page R.E. (1995) Linkage map of the honey bee, Apis mellifera, based on RAPD markers, Genetics 139, 1371-1382.

Ihering H. (1903) Biologie der stachellosen Honigbienen Brasiliens, Zool. Jahrb. 29, 179-287.

Katiyar S.K., Chandel G., Tan Y., Zhang Y., Huang B., Nugaliyadde L., Fernando K., Bentur J.S., Inthavong S., Constantino S., Bennett J. (2000) Biodiversity of Asian rice gall midge (Orseolia oryzae Wood Mason) from five countries examined by AFLP analysis, Genome 43, 322-332.

Kerr W.E. (1946) Formação de castas no gênero Melipona (Illiger, 1806) - nota prévia, An. Esc. Sup. Agric. "Luiz de Queiroz" 3, 299-312.

Kerr W.E. (1950) Genetic determination of castes in the genus Melipona, Genetics 35, 143-152.
Machado M.F.P.S., Contel E.P.B. (1991) Glycerol-3phosphate dehydrogenase (G-3-PDH; EC 1.1.1.8) variation in Brazilian stingless bees and wasp species, Biochem. Genet. 29, 255-260.

Michener C.D. (2000) The Bees of the World, John Hopkins University Press, Baltimore.

Mueller U.G., Wolfenbarger L.L. (1999) AFLP genotyping and fingerprinting, Trends Ecol. Evol. 14, 389-394.

Nogueira-Neto P. (1997) Vida e Criação de Abelhas Indígenas Sem Ferrão, Editora Nogueirapis, São Paulo.

Nybom H. (2004) Comparison of different nuclear DNA markers for estimating intraspecific genetic diversity in plants, Mol. Ecol. 13, 1143-1155.

Palmer K.A., Oldroyd B.P., Quezada-Euan J.J.G., Paxton R.J., May-Itza W.D. (2002) Paternity frequency and maternity of males in some stingless bee species, Mol. Ecol. 11, 2107-2113.

Paxton R.J. (2000) Genetic structure of colonies and a male aggregation in the stingless bee Scaptotrigona postica, as revealed by microsatellite analysis, Insectes Soc. 47, 63-69.

Paxton R.J., Thorén P.A., Tengö J., Estoup A., Pamilo P. (1996) Mating structure and nestmate relatedness in a communal bee, Andrena jacobi (Hymenoptera, Andrenidae), using microsatellites, Mol. Ecol. 5, 511-519.

Paxton R.J., Weissschuh N., Engels W., Hartfelder K., Javier J., Quezada-Euan G. (1999) Not only single mating in stingless bees, Naturwissenschaften 86 , 143-146.

Paxton R.J., Bego L.R., Shah M.M., Mateus S. (2003) Low mating frequency of queens in the stingless bee Scaptotrigona postica and worker maternity of males, Behav. Ecol. Sociobiol. 53, 174-181.

Peters J.M., Queller D.C., Imperatriz-Fonseca V.L., Roubik D.W., Strassmann J.E. (1999) Mate number, kin selection and social conflicts in stingless bees and honeybees, Proc. R. Soc. Lond. Ser. BBiol. Sci. 266, 379-384.

Piepho H.-P., Koch G. (2000) Codominant analysis of banding data from a dominant marker system by normal mixtures, Genetics 155, 1459-1468.

Ratnieks F.L.W. (2001) Heirs and spares: caste conflict and excess queen production in Melipona bees, Behav. Ecol. Sociobiol. 50, 467-473.

Reineke A., Karlovsky P., Zebitz C.P.W. (1998) Preparation and purification of DNA from insects for AFLP analysis, Insect Mol. Biol. 7, 95-99.

Rocha M.P., Pompolo S.G., Dergam J.A., Fernandes A., Campos L.A.O. (2002) DNA characterization and karyotypic evolution in the bee genus Melipona (Hymenoptera, Meliponini), Hereditas 136, 19-27.

Rueppell O., Pankiw T., Nielsen D.I., Fondrk K., Beye M., Page R.E. (2004) The genetic architecture of 
the behavioral ontogeny of foraging in honeybee workers, Genetics 167, 1767-1779.

Sanguinetti C., Dias Netto E., Simpson A.J.G. (1994) Rapid silver staining and recovery of PCR products separated on polyacrylamide gels, Biotechniques 17, 209-214.

Simmons L.W., Beveridge M., Krauss S. (2004) Genetic analysis of parentage within experimental populations of a male dimorphic beetle, Onthophagus taurus, using amplified fragment length polymorphism, Behav. Ecol. Sociobiol. 57, 164-173.

Smith D.R., Palmer M.R., Otis G., Damus M. (2003) Mitochondrial DNA and AFLP markers support species status of Apis nigrocincta, Insectes Soc. 50, 185-190.

Suazo A., Hall H.G. (1999) Modification of the AFLP protocol applied to honey bee (Apis mellifera L.) DNA, Biotechniques 26, 704-709.

Tan Y.-D., Wan C., Zhu Y., Lu C., Xiang Z., Deng H.W. (2001) An amplified fragment length polymorphism map of the silkworm, Genetics 157, 12771284.

Tavares M.G., Ribeiro E.H., Campos L.A.O., Barros E.G., Oliveira M.T.V.A. (2001) Inheritance pattern of RAPD markers in Melipona quadrifasciata (Hymenoptera: Apidae, Meliponinae), J. Hered. 92, 279-282.

Tóth E., Strassmann J.E., Nogueira-Neto P., Imperatriz-Fonseca V.L., Queller D.C. (2002) Male production in stingless bees: variable outcomes of queen-worker conflict, Mol. Ecol. 11, 2661-2667.
Tóth E., Queller D.C., Dollin A., Strassmann J.E. (2004) Conflict over male parentage in stingless bees, Insectes Soc. 51, 1-11.

Velthuis H.H.W., Koedam D., Imperatriz-Fonseca V.L. (2005) The males of Melipona and other stingless bees, and their mothers, Apidologie 36, 169-185.

Velthuis H.H.W., de Fries H., Imperatriz-Fonseca V.L. (2006) The polygyny of Melipona bicolor: scramble competition among queens, Apidologie 37, 222-239.

Vos P., Rogers R., Bleeker M., Reijans M., Van de Lee T., Hornes M., Fritjers A., Pot J., Peleman J., Kuipe M., Zabeau M. (1995) AFLP: a new technique for DNA fingerprinting, Nucleic Acids Res. $23,4414$.

Waldschmidt A.M., Marco-Junior P., Barros E.G., Campos L.A.O. (2002) Genetic analysis of Melipona quadrifasciata Lep. (Hymenoptera: Apidae, Meliponinae) with RAPD markers, Braz. J. Biol. 62, 923-928.

Waldschmidt A.M., Salomão T.M.F., Barros E.G., Campos L.A.O. (1997) Extraction of genomic DNA from Melipona quadrifasciata (Hymenoptera: Apidae, Meliponinae), Genet. Mol. Biol. 20, 421-423.

Weinlich R., Francisco F.O., Arias M.C. (2004) Mitochondrial DNA restriction and genomic maps of seven species of Melipona (Apidae: Meliponini), Apidologie 35, 365-370.

Wong A., Forbes M.R., Smith M.L. (2001) Characterization of AFLP markers in damselflies: prevalence of codominant markers and implications for population genetic applications, Genome 44, 677-684. 